\title{
Forskriften sykehusene bør frykte
}

\author{
Artikkelen ble publisert først på nett 12.1. 2012.
}

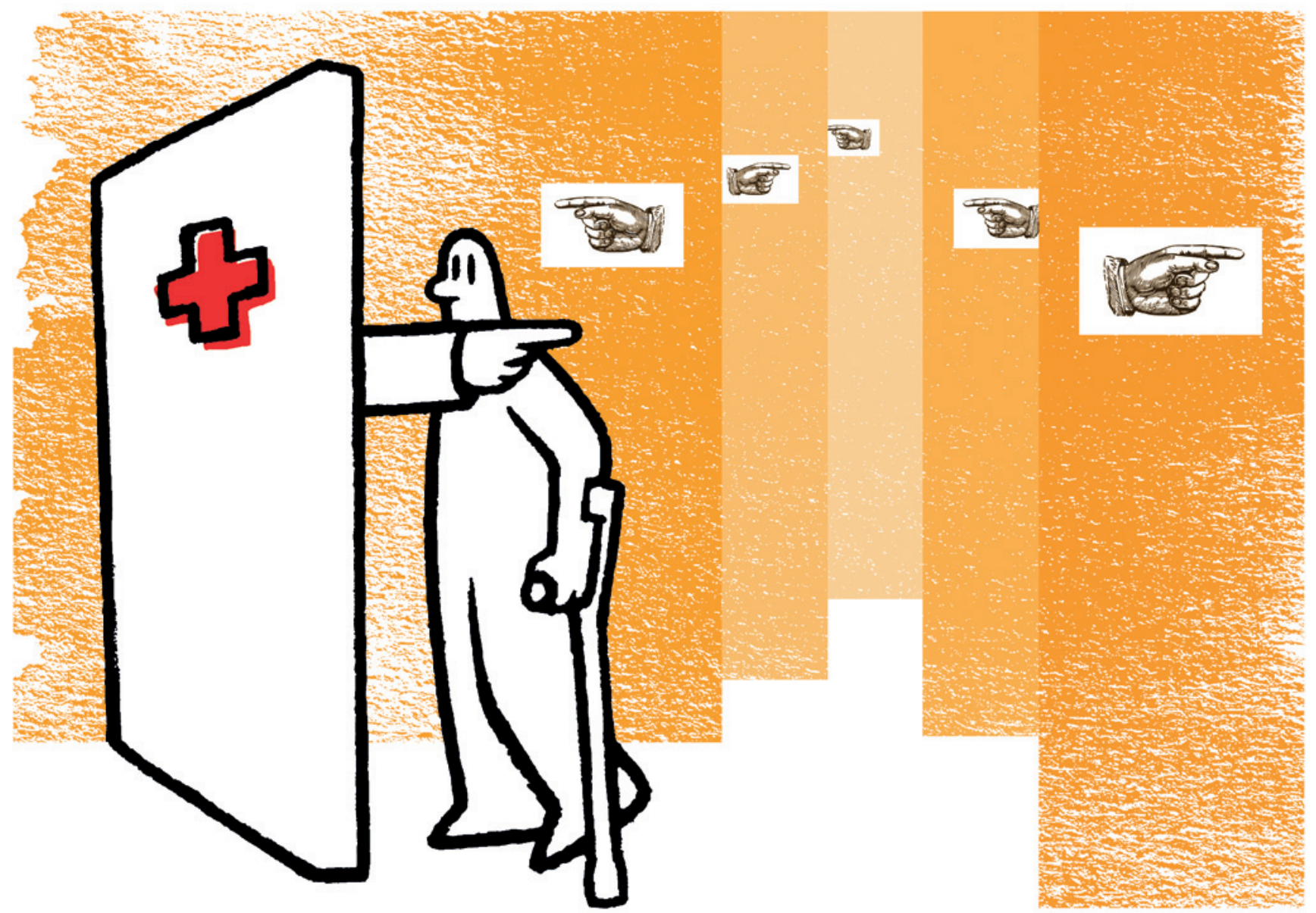

Illustrasjon @ C Supernøtt popsløyd

Helse- og omsorgsdepartementet offentliggjorde rett før jul utkast til revidert forskrift om fastlegeordningen i kommunene (1). Forslaget legger opp til en detaljert styring av fastlegenes tilgjengelighet for både pasienter og kommunale tjenester, oppsøkende virksomhet og økte rapporteringskrav. Kommunene skal kunne bruke økonomiske sanksjoner overfor leger som ikke oppfyller kravene. Grensesnittet mellom kommunal kontroll og styring og Helsetilsynets faglige tilsynsrolle er uklart beskrevet. Fastlegenes mulighet for faglig begrunnet prioritering vil bli svekket, og det oppstår risiko for at de sykeste rykker bakover i køen, mens fastlegene vil måtte henvise mange flere pasienter til spesialisthelsetjenesten.

Etter innføring av kommunehelsetjenesteloven i 1984 ble rekruttering av allmennleger et tiltakende problem. Utsiktene til en fastlegeordning og innføringen av denne førte til bedring. Etter innføring av fastlegeordningen fra 2001 har det allikevel vært en økende forgubbing. Mer enn en tredel av fastlegene er nå over 55 år, noe som er en fordobling av denne andelen i perioden 2001-10 (2).
I forarbeidene til fastlegeordningen skrev departementet (3): «Den mest kritiske faktoren er tilstrekkelig tilgang på leger til primærhelsetjenesten generelt.» Helsedirektoratet skriver i sin utviklingstrekkrapport for 2008: «Det er viktig å sikre gode tjenester på det laveste effektive omsorgsnivået. Det er i dag et kapasitetsproblem i fastlegeordningen som fører til et kvalitetsproblem for hele helsetjenesten...» (4).

Daværende helse- og omsorgsminister Bjarne Håkon Hanssen tok dette innover seg da han i 2008 varslet at en samhandlingsreform var avhengig av en kraftig styrking av legetjenesten i kommunene. Men i dag synes departementet å mene at problemet er dårlig organisering ved fastlegekontorene, kapasitetsutfordringene er ikke lenger et tema.

I det fremlagte forskriftsforslaget er koblingen mellom krav til tilgjengelighet og økonomiske sanksjoner problematiske fra et sykehus- og samhandlingsperspektiv. Kravet om at alle henven- 
delser til fastlegen skal besvares innen to minutter på telefon og at ingen skal vente lenger enn 48 timer - eller kanskje fem virkedager, avhengig av hva departementet til slutt faller ned på - er dramatisk, fordi det vil måtte føre til en dreining av fastlegenes praksis mot flere (og dermed kortere) konsultasjoner. Departementet viser til at liknende krav er avtalefestet i England og Danmark. Man unnlater å drøfte at dette er koblet til en helt annen faglig kultur med til dels svært korte konsultasjoner, omfattende bruk av hjelpepersonell til selvstendig konsultasjonsvirksomhet og det faktum at det $\mathrm{i}$ disse to land ikke er egenandeler på allmennlegetjenester.

Den norske fastlegen har ikke rett til å bruke hjelpepersonell til selvstendige konsultasjoner. Dessuten må pasientene våre betale stadig mer av tjenestene selv, og ønsker selvsagt å få løst flest mulige problemer ved ett besøk. Lang reise til legebesøk for mange bidrar til det samme.

En departemental marsjordre om kortere og flere konsultasjoner er farlig for både pasient og lege. For at en slik dreining av praksis ikke skal føre til at man overser sykdom eller gir feilaktig behandling, vil den enkelte fastlege måtte kompensere med å henvise flere pasienter til spesialisthelsetjenesten. Forsvarlighetskravene i lov om helsepersonell slik de er beskrevet i $\S 4$ gir fastlegen tydelige føringer for dette: «Helsepersonell skal innrette seg etter sine faglige kvalifikasjoner, og skal innhente bistand eller henvise pasienter videre der dette er nødvendig og mulig.»

I den grad kommunene vil benytte de økonomiske sanksjonene som foreslås, vil de neppe ha medisinskfaglig kompetanse til å ta stilling til om leger tilbyr nok forebygging, sykebesøk eller oppsøkende virksomhet hos dem som ikke selv tar kontakt med helsetjenesten. Derfor vil kommunene trolig i hovedsak måle de tekniske tilgjengelighetskravene i forskriften dersom denne skulle bli vedtatt. Maksimalt to minutters ventetid før svar på telefonen og maksimalt 2-5 dagers ventetid på alt som ikke krever hjelp samme dag lar seg relativt lett måle og vil derfor trolig bli mest førende for fastlegenes tilpasning til de fremlagte forslag. Attester og aneurismer, kreft og krangel med arbeidsgiver skal heretter ha den samme prioritet, slik forslaget må forstås. De sykeste blir taperne.

Litt forenklet kan man si at fastlegene må være svært tilgjengelige på sitt kontor for at ikke kommunen skal ta pengene deres, og svært raske med å henvise pasienter videre for at ikke Helsetilsynet skal ta autorisasjonen deres.

Konsekvensene for helseforetakene av små endringer i fastlegenes henvisningsatferd er dramatiske. Om lag 1,7 millioner pasienter ble undersøkt eller behandlet i somatiske sykehus i Norge i 2010, ifølge Statistisk sentralbyrå (5). Av disse var det ca. 850000 døgnopphold. Videre ble det utført ca 4,7 millioner polikliniske konsultasjoner ved somatiske sykehus i 2010, hvorav en høy andel er kontroller og ikke nyhenvisninger (5).

I 2009 hadde befolkningen 27 millioner kontakter med fastlege eller legevakt (6). Hvis allmennlegene som følge av de foreslåtte tilgjengelighetskrav velger å legge inn bare en prosent flere av disse pasientene enn det de gjør i dag, vil antall innleggelser i sykehus øke med ca. $30 \%$, til over 1,1 million.
Om allmennlegene henviser én pasient mer hver virkedag til poliklinisk vurdering i spesialisthelsetjenesten, gir det en vekst på omtrent en million nyhenvisninger per år, noe som vil kunne lamme sykehusenes poliklinikker. For å imøtekomme kravet om telefontilgjengelighet innenfor uendrede økonomiske rammer kan den enkelte fastlegevirksomhet omprioritere sitt hjelpepersonell. Dette vil i hovedsak måtte skje ved at personell tas bort fra laboratoriet for å svare på innkommende telefoner. Dermed vil flere pasienter måtte henvises til sykehusenes laboratoriepoliklinikker, hvor man neppe har hjemmel til å nekte dem service.

Det tas antakelig laboratorieprøver ca. 15 millioner ganger i året hos fastlegene, og mange analyseres på legekontoret. Et betydelig prøvetakings- og analysevolum vil med en ny forskrift måtte påregnes å ende opp i helseforetak og private laboratorier, med allerede begrenset kapasitet. Ulempene for pasientene blir åpenbare.

Utkastet til ny forskrift har et overordnet målbilde man knapt kan være uenig i. Bedre tilgjengelighet og høyere kvalitet kan oppnås gjennom et tett samarbeid hvor man kan finne en balanse og utvikling over tid - etter hvert som en styrking av fastlegevirksomhetene gjør det gjennomførbart.

Helse- og omsorgsdepartementet ønsker i stedet en endret innretning av innsatsen fra norske fastleger som med stor sannsynlighet vil føre til økt press på spesialisthelsetjenesten, stikk i strid med samhandlingsreformens intensjoner om å flytte mer av medisinsk utredning, behandling og omsorg til kommunene.

Intensjonene med forslaget er sikkert de aller beste, men det finnes veier man ikke bør gå, ei heller om de er brolagt med de beste intensjoner.

\section{Jan Emil Kristoffersen}

jan.emil.kristoffersen@ahus.no

Jan Emil Kristoffersen (f. 1953) har tidligere arbeidet som helsebyråkrat og allmennlege og ledet Allmennlegeforeningen fra 2005 til 2009. Han er nå overlege ved Avdeling for samhandling, Akershus universitetssykehus. Ingen oppgitte interessekonflikter.

\section{Litteratur}

1. www.regjeringen.no/nb/dep/hod/pressesenter/pressemeldinger/2011/ kortere-ventetid-hos-fastlegen.html?id=667730 (3.1.2012).

2. www.helsedirektoratet.no/finansiering/refusjonsordninger/tall-og-analyser/ fastlege/Sider/fastlegestatistikken-2010.aspx (10.1.2012).

3. Ot.prp. nr. 99 (1998-99). Om lov om endringer i lov 19. november $1982 \mathrm{nr} .66 \mathrm{om}$ helsetjenesten i kommunene og i visse andre lover (fastlegeordningen). www.regjeringen.no/nb/dep/hod/dok/regpubl/otprp/19981999/ otprp-nr-99-1998-99-.html?id=160124 (3.1.2012)

4. Skapes helse, skapes velferd - helsesystemets rolle i det norske samfunnet. Utviklingstrekkrapport 2008. IS 1545-2008. Oslo: Helsedirektoratet, 2008.

5. www.ssb.no/emner/03/02/pasient/ (2.1.2012).

6. Analyserapport aktivitetsstatistikk for 2009. Tønsberg: HELFO, 2011. 